\title{
Measurement of Radioelements (U, Th and K) Concentration Using Ground Radiometric and Statistical Studies at Gaya North-Western Nigeria
}

\author{
Ahmed, A. L., Abubakar, W. M. and Abubakar, A. \\ Department of Physics, Faculty of Physical Sciences, Ahmadu Bello University, Zaria, Kaduna State, Nigeria
}

\begin{abstract}
Detailed ground radiometric survey was conducted at Gaya North Western Nigeria to characterize the radioelement potential in the region as reported in airborne spectrometric map produced by Hunting Geology and Geophysics LTD (1975). Compact Spectrometer Gamma Surveyor was used to measured radioelements along twenty one profiles $1 \mathrm{~km}$ each. The measurement time was set at 5 minutes for sensing the concentration of Uranium, Thorium and Potassium. The research result gave mean concentration of the radioelement $U$, Th, $K$ as $17.527 \mathrm{ppm}, 56.09 \mathrm{ppm}$ and $4.1092 \%$ respectively in the order of $(\mathrm{Th}>\mathrm{U}>\mathrm{K})$, absorbed dose rate values ranging from $33.45 \mathrm{nGyph}^{-1}$ to $676.49 \mathrm{nGyph}^{-1}$ with average value of 48.3 $\mathrm{nGyph}^{-1}$ which is lower than the world average value. Research successfully revealed Uranium and Thorium are most enriched in the youngest, most felsic and most potassic members of igneous rocks which is a good indicator for magmatic to postmagmatic alteration processes.
\end{abstract}

Keywords: Gamma Surveyor, Radiometric, Radioelement, Dose rate

\section{INTRODUCTION}

$\mathrm{T}$ he radiometric method is a geophysical technique used to estimate concentrations of the radioelements potassium, uranium and thorium by measuring the gamma-rays which the radioactive isotopes of these elements emit during radioactive decay.

Radiometric investigations are being successfully employed in recent years, in addition to the usual prospecting for radioactive minerals, to solve some of geological problems, such as tracing of tectonic zones, mapping of different geological formations and locating mineralized zones (Preeti et al, 2013)

At least 20 naturally occurring elements are now known to be radioactive, uranium (U), thorium (Th) and an isotope of potassium $(\mathrm{K})$ are of importance in exploration. The two elements, uranium and thorium are important today as a source of fuel for the generation of heat and power in nuclear reactors (Telford et al., 1990).

All rocks and soils contain radioactive isotopes, and almost all the gamma-rays detected near the earth's surface is the result of the natural radioactive decay of potassium, uranium and thorium. The gamma-rays are packets of electromagnetic radiation characterised by their high frequency and energy.
They are quite penetrating, and can travel about 35 centimetres through rock and several hundred metres through the air. Each gamma ray has a characteristic energy, and measurement of this energy allows the specific potassium, uranium and thorium radiation to be diagnosed.

\section{STUDY OBJECTIVE}

The regional airborne spectrometric map conducted by Hunting Geology and Geophysics LTD (1975) produced ariel spectrometric map of Gaya sheet 82 that showed some radiometric anomalies in part of Dutse LGA in present Jigawa State having the following amplitude; Potassium anomaly is $14 \mathrm{~m}$, Uranium anomaly is $23 \mathrm{~m}$, and Thorium anomaly has $31 \mathrm{~m}$, and Total Count have an amplitude of $345 \mathrm{~m}$, it is on this note that ground in-stu radiometric survey was conducted to confirm the potentials of uranium, thorium, and potassium mineralization in the area under the study as observed on the airborne spectrometric map. This work characterized areas with most promising radioelements within the study area.

\section{Location and Vegetation of the Study Area}

The Area under study, Dutse LGA is located between latitudes $11^{\circ} 44^{\prime} 10.59^{\prime \prime} \mathrm{N}$ and $11^{\circ} 44^{\prime} 43.53^{\prime \prime} \mathrm{N}$ and longitude $9^{\circ} 21^{\prime} 5.63^{\prime \prime E}$ and $9^{\circ} 24^{\prime} 38.57^{\prime \prime E}$ on the topographic map sheet 82. Dutse Local Government Area is bordered by Ringim and Jahun Local Government Area to the North, Birnin Kudu Local Government Area to the South, Kiyawa and Gaya Local Government Areas to the East and West respectively (Aliyu, 2005).

Most parts of the study area lie within the Sudan Savannah with elements of Guinea Savannah in the southern part. Total forest cover in the State is very much below national average of $14.8 \%$ (Garba, 1998). Due to both natural and human factors, forest cover is being depleted, making it vulnerable to desert encroachment. The Study area enjoys vast fertile arable land to which almost all tropical crops could adapt, thus constituting one of its highly prized natural resources. The Sudan Savannah vegetation zone is also made up of vast grazing lands suitable for livestock production. 


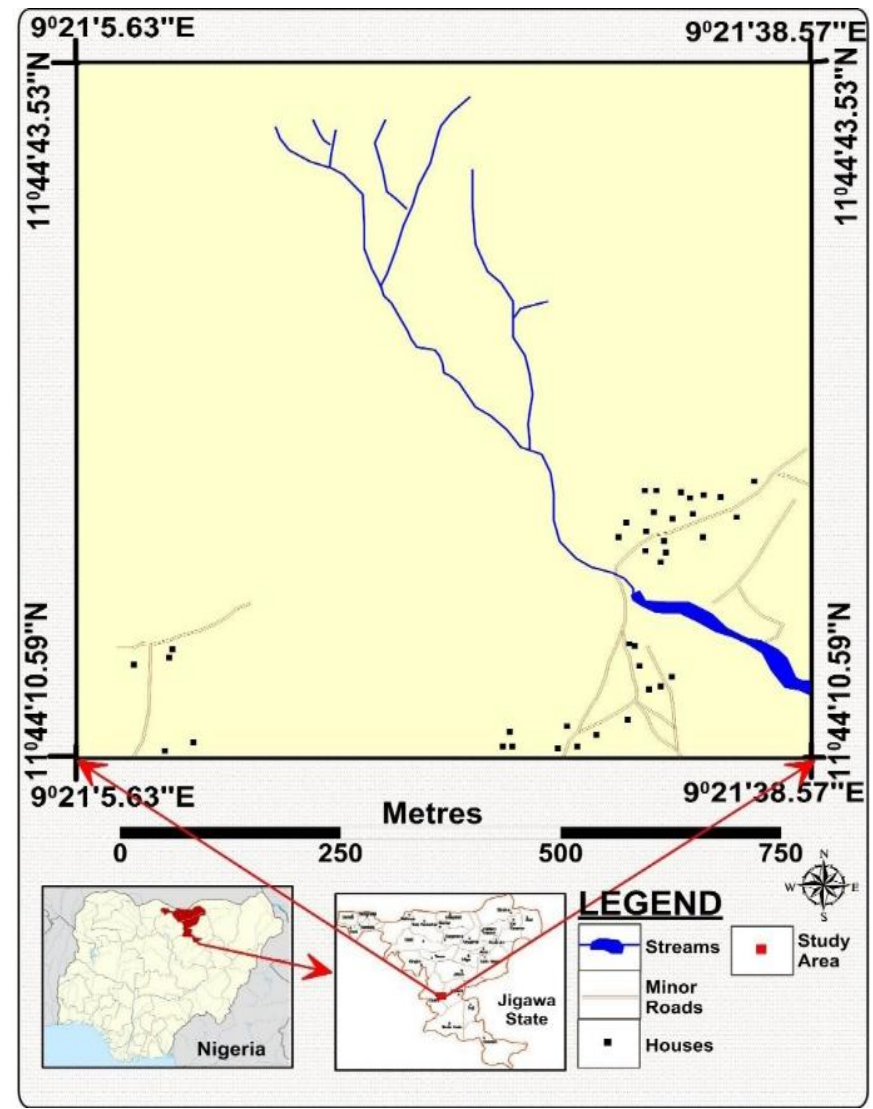

Figure 1: Location of the Study Area

\section{Geology of the Study Area}

The Nigerian younger granite complexes are known to be mineralogically heterogenous with variations in their textures that are attributable to the proximity of the roofs of the batholiths (Turner, 1983). They are composed of a wide variety of rock types including, but not limited to hornblende porphyry, hornblende biotite granites, biotite granites, fayalite granites, riebeckites granites, and some basic to intermediate rocks (mostly named after the most abundant mafic mineral content). The Basement Complex rocks in the study area are Precambrian in origin with granitic outcrops including Mesozoic younger granite and Pan African Older granite (Olofin, 1987). In the study area, Turner (1983) also reported the occurrence of rocks of the Younger Granites series so termed because they are Jurassic in age, as well as volcanic, and occasional younger dykes and flows. Individual younger granite suites are known to contain different rock types in the various sub provinces despite their age differences that decrease toward the south, suggesting that their emplacement was fundamentally controlled by thermal anomaly in the mantle or lower crust but not related to any orogenic activity and are thus referred to as unorogenic (Garba, 1992).

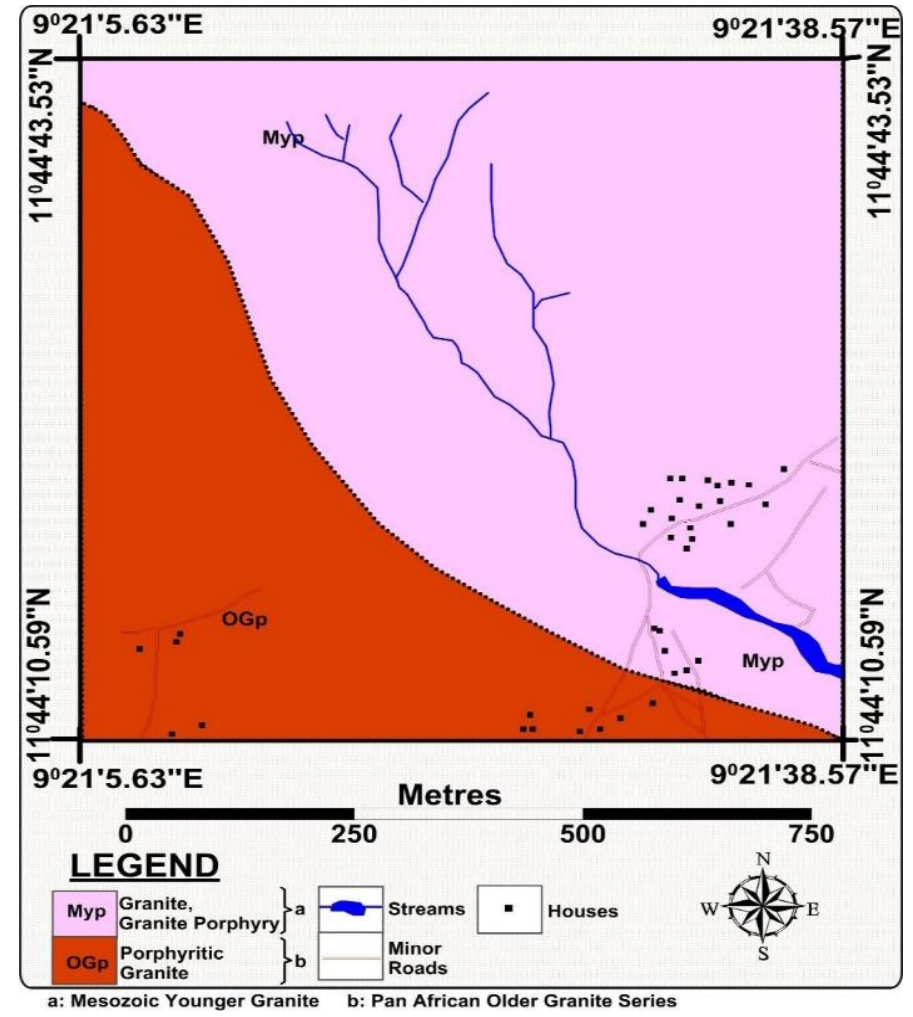

Figure 2: Geological Map of the Study Area

\section{III.INSTRUMENTATION AND METHODOLOGY}

The compact spectrometer gamma surveyor instrument always measures the complete spectrum, from which it evaluates the count per second (cps) values in Region of Interests (ROIs) and calculates the concentrations of elements $\mathrm{U}$ (ppm), Th (ppm) and $\mathrm{K}(\%)$. The concentration of $\mathrm{K}$ is determined directly. The eU and eTh concentrations are based on detection of radioisotopes $214 \mathrm{Bi}$ and $208 \mathrm{Tl}$ that are parts of the related disintegration series.

The instrument transforms incident gamma radiation into visual readout of radioactive intensity as a function of the natural radioactive material present in geologic phenomena, the possible measurement type it does are; borehole, profile and point. We adopted profile technique over $1 \mathrm{~km} \times 1 \mathrm{~km}$ square for four days. The entire study area was gridded into 21 profiles with both inter-profile and inter-station spacing of $50 \mathrm{~m}$ having total of 441 points. Figure 3 shows pattern of gridding and movement on field.

For a required accuracy of the results, meas time (time of the measurement on one point) was set at 5 minutes for valid order of $0.1 \%$ for $\mathrm{K}$ concentration and of $1 \mathrm{ppm}$ for $\mathrm{eU}$ and eTh concentration, shorter measuring time causes decreased stability of reached results. The radioelement and natural dose rates measurements were automatically calculated and displayed at each station (Table 1). The acquired data from Ground Gamma Ray Spectromery Survey carried out on the anomaly of interest were analyzed and interpreted to delineate and characterize the study area in 
terms of its radioelement content. Mean $(x)$ as the ratio of the sum of the observed values to the number of observations, standard deviation $(\sigma)$ which gives an idea of how close the entire set of data is to the average value and coefficient $(r)$ that measures the degree of linear relationship between two variables were computed and tabulated using equations (1-3) respectively.

$$
\mu=\frac{\sum_{i=1}^{N} x_{i}}{N}
$$

$$
\begin{gathered}
\sigma=\sqrt{\frac{\sum(X-\mu)^{2}}{N}} \\
r=\frac{n\left(\sum x y\right)-\left(\sum x\right)\left(\sum y\right)}{\sqrt{\left[n \sum x^{2}-\left(\sum x\right)^{2}\right]\left[n \sum y^{2}-\left(\sum y\right)^{2}\right]}}
\end{gathered}
$$

However, background readings were taken from nearby waterbodies for background corrections for accurate analysis outcomes (Table 1)

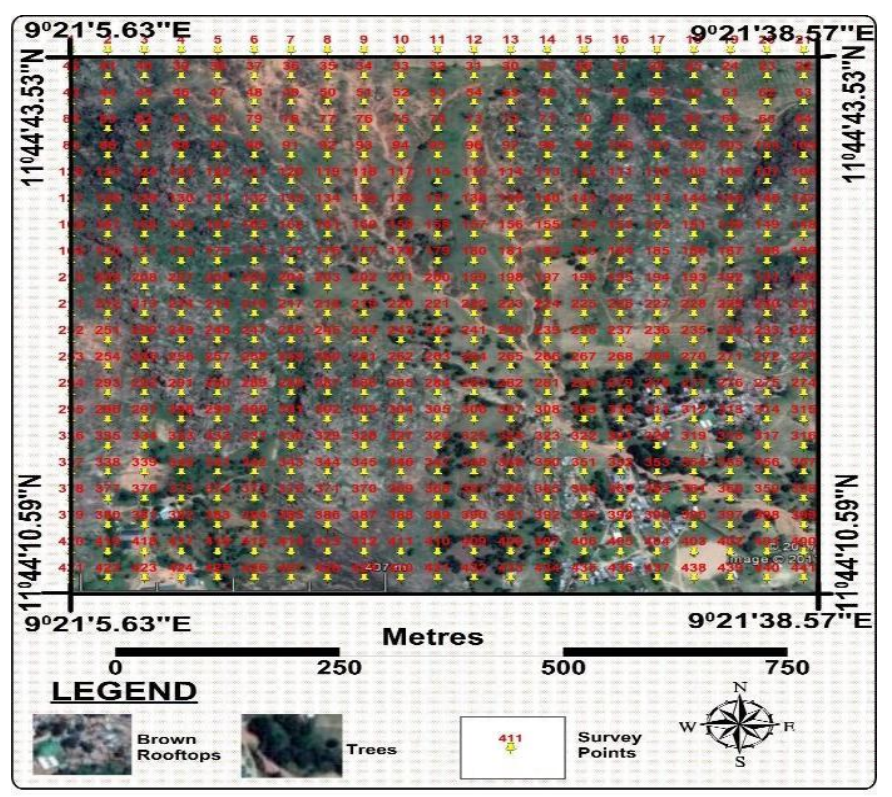

Figure 3: Survey Stations and Profile Orientation

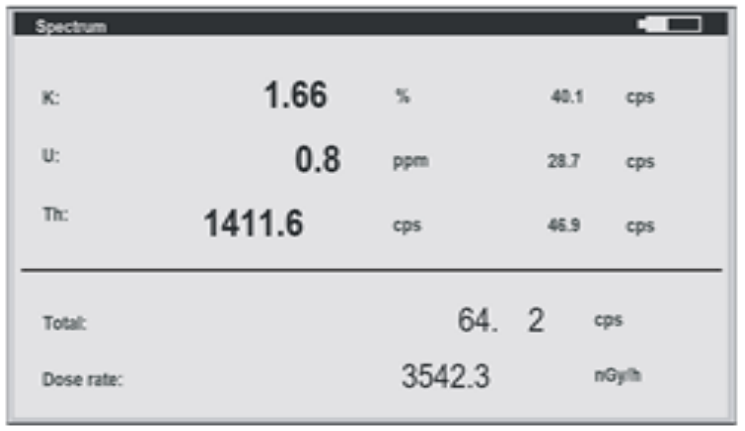

Figure 4: Window of measurement from Spectrometer

Table 1: Background reading Taken from Warwade Dam

\begin{tabular}{|c|c|c|c|c|}
\hline & $\mathrm{K}(\%)$ & $\mathrm{U}(\mathrm{ppm})$ & $\mathrm{Th}(\mathrm{ppm})$ & $\begin{array}{c}\text { Total count } \\
(\mathrm{cps})\end{array}$ \\
\hline & 0.13 & 0.56 & 2.4 & 126.8 \\
\hline & 0.12 & 0.48 & 2.6 & 122.6 \\
\hline & 0.12 & 0.56 & 2.8 & 128.8 \\
\hline Average & 0.14 & 0.62 & 2.6 & 126.6 \\
\hline
\end{tabular}

\section{RESULTS AND DISCUSSION}

Two mods of result presentation were adopted in this research; graphical and statistical modes using Oasis Montaj, SPSS and Microsoft Excel.

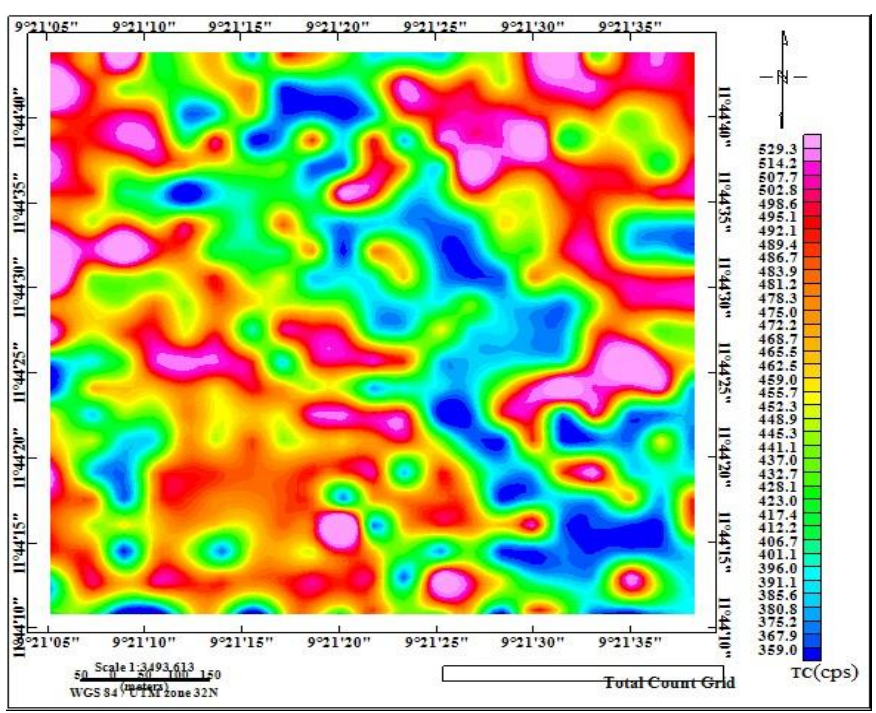

Figure 5: Total Count Map

Figures 5-8 were generated using Oasis Montaj and are respectively the total count (TC in cps), equivalent uranium (eU in ppm), equivalent thorium (eTh in $\mathrm{ppm}$ ) and potassium ( $\mathrm{K}$ in \%) maps of the data obtained on the field. 
The total count map (Fig. 5) indicated radiometric anomalies in the north-eastern and south-western part of the map with the values ranging from $460 \mathrm{cps}$ to $550 \mathrm{cps}$ while low values ranging from $320 \mathrm{cps}$ to $400 \mathrm{cps}$ are observed along NW-SE direction of the area. The concentration of uranium is higher around SW and NE as well NW flank of the study area ranging from $23 \mathrm{ppm}$ to $35 \mathrm{ppm}$ (Fig. 6) while lower concentration of uranium is observed in the southeastern, north-north and around central part of the study area ranging from $1 \mathrm{ppm}$ to $22 \mathrm{ppm}$.

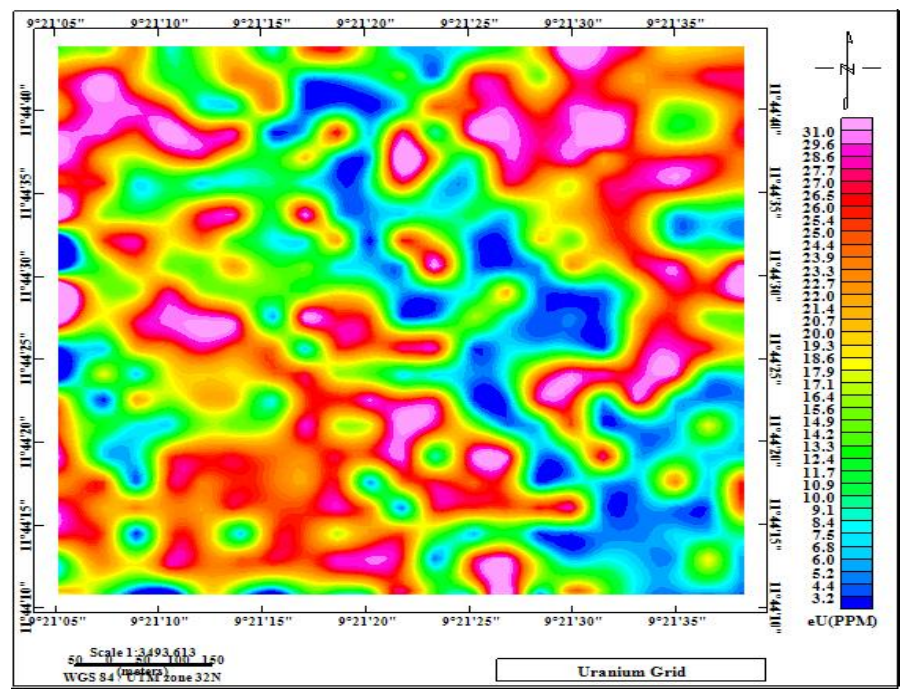

Figure 6: Uranium Concentration Map (eU in PPM)

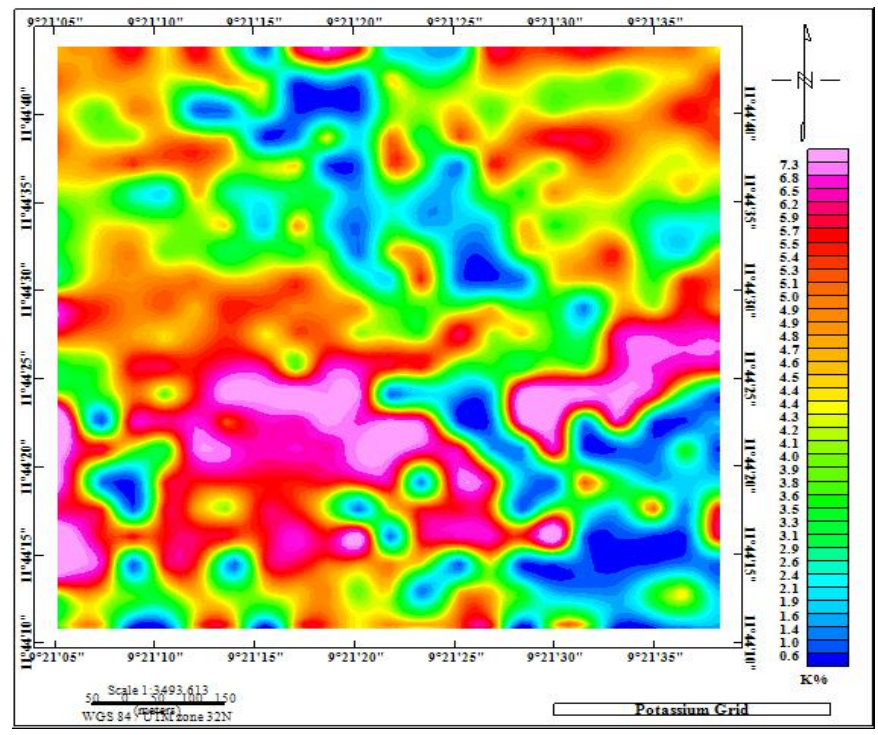

Figure 7: Potasium Concentration Map (K-\%)

Potassium concentration is moderate to high in the northeastern, north-western, south-western and south-eastern region ranging from $4.4 \%$ to $8 \%$ while lower concentration is observed in the rest of the area with values ranging from 0.5 $\%$ to $4.3 \%$ (Fig. 7 ).

The thorium map (Fig.8) shows few regions with high concentration of thorium in the north-eastern and north- western part ranging from $95 \mathrm{ppm}$ to $130 \mathrm{ppm}$ while the central parts, south-eastern region records low to lower anomalies ranging from $10 \mathrm{ppm}$ to $42.4 \mathrm{ppm}$ in the study area.

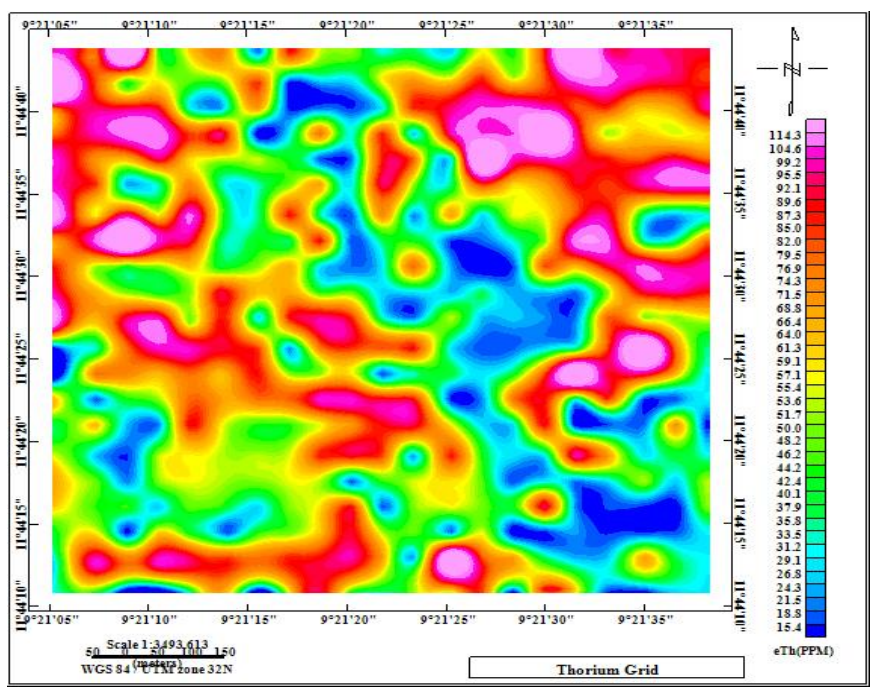

Figure 8: Thorium Concentration Map (eTh-PPM)

Radiometric ratio analysis was carried out for effective radioelements and lithological variations within the study area. Fig. 9 is the Uranium to Thorium (eU/eTH) ratio map shows a low increase in uranium to thorium concentration ranging from 0.1 to 0.8 indicating average concentration of Uranium over thorium. In the U/K ratio map (Fig. 10), there is preferential enrichment of potassium to uranium as most of the area has low $\mathrm{U} / \mathrm{K}$ ratio values while uranium enrichment is observed in the southeastern and north-western end of the study area.

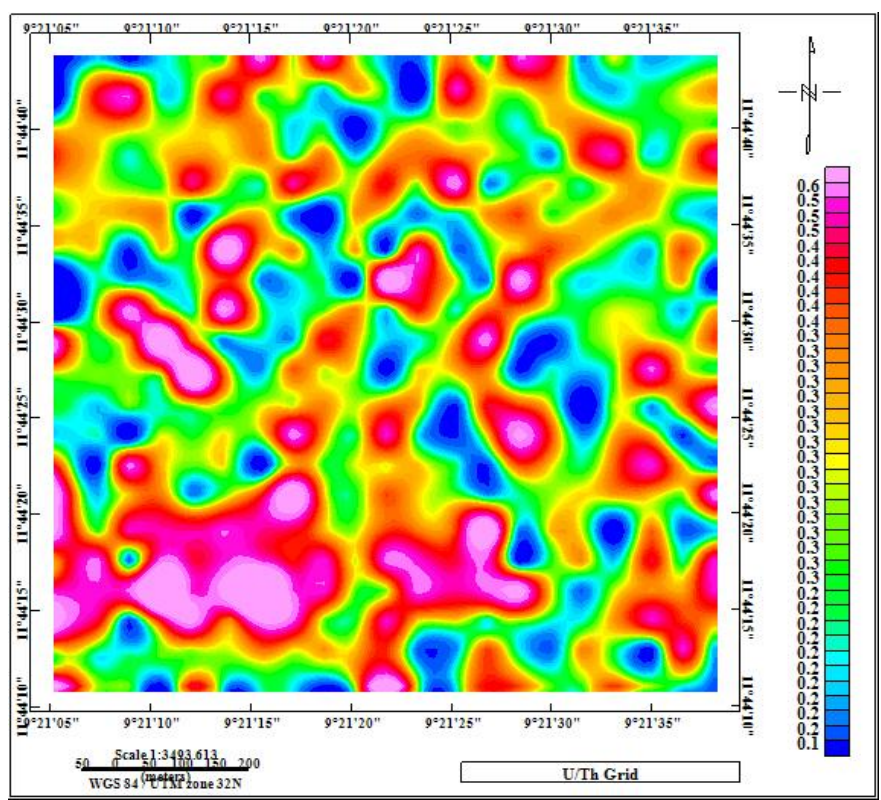

Figure 9: U/Th Ratio Map 


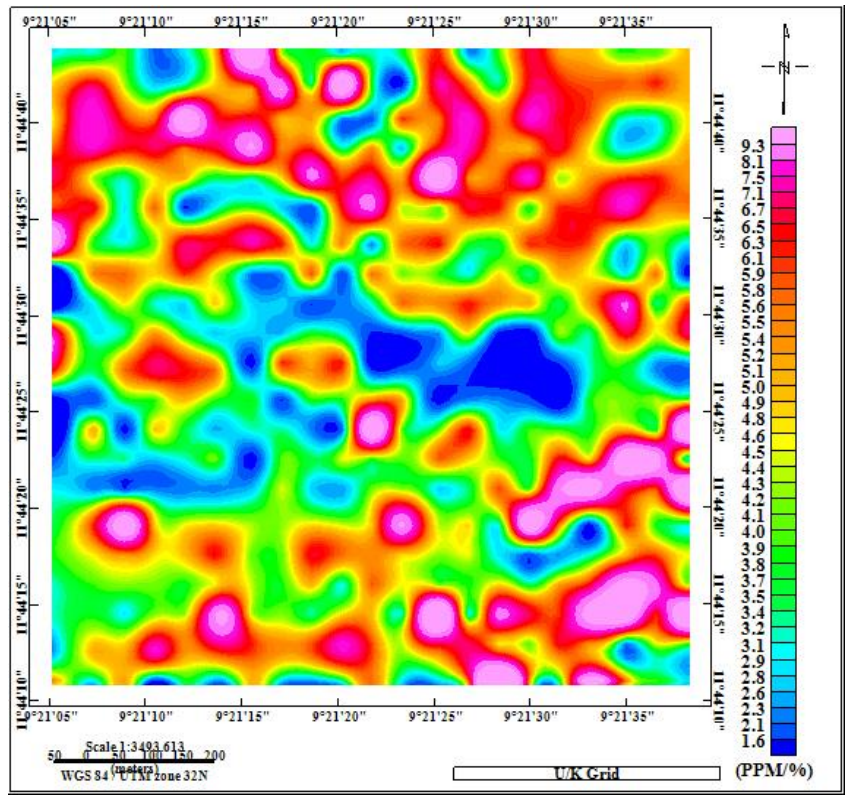

Figure 10: U/K Ratio Map

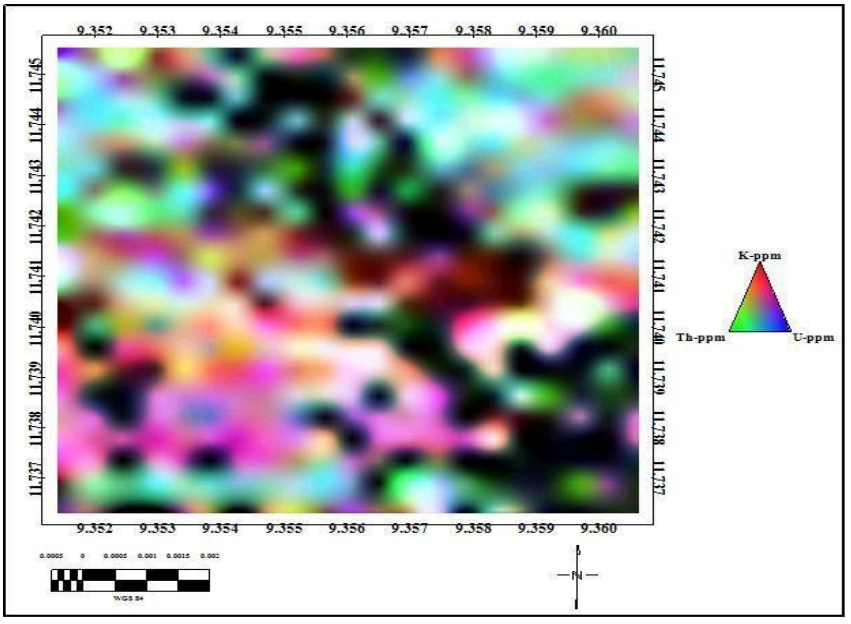

Figure 11: Standard Ternary Map

A standard ternary image (Figure 11) is plotted in RGB (Red, Green and Blue) using Oasis Montaj where $\mathrm{R}=$ Potassium, $\mathrm{G}=$ Thorium and $\mathrm{B}=\mathrm{Uranium}$. High concentration of the three (3) radioelements tend to white while low concentration of the three (3) radioelements tend to black (Salem, 2005). Concentration of the radioelements is higher (i.e, the white portions) in the southwest and north-eastern part of the area while low concentrations are observed in the northeastern, north-north and central parts.

Statistical data analysis techniques employed in this research work includes mean, minimum, maximum, standard deviation and coefficient of correlation of values of the radioelement concentrations using SPSS. The purpose is to evaluate/determine the statistical correlations and mathematical relationship which may exist between the radiation parameter investigated using equation 1-3 above.
The statistical analysis of the radionuclides and dose rate for the data acquired are presented in the Table 3 while the activity ratios $(\mathrm{U} / \mathrm{Th}, \mathrm{U} / \mathrm{K}, \mathrm{Th} / \mathrm{U}, \mathrm{Th} / \mathrm{K}, \mathrm{K} / \mathrm{U}$ and $\mathrm{K} / \mathrm{Th})$ are given in Table 4.

Table 3: Statistical Analysis of Radionuclides

\begin{tabular}{|c|c|c|c|c|}
\hline Radionuclide & Min & Max & Mean & $\begin{array}{c}\text { Standard } \\
\text { Deviation }\end{array}$ \\
\hline $\mathrm{eU}(\mathrm{ppm})$ & 1.2 & 39.2 & 17.529 & 9.8907 \\
\hline $\mathrm{eU}(\mathrm{cpc})$ & 0.7 & 6.9 & 2.988 & 1.6120 \\
\hline $\mathrm{eTh}(\mathrm{ppm})$ & 7 & 187 & 59.06 & 33.522 \\
\hline $\mathrm{eTh}(\mathrm{cpc})$ & 0.3 & 6.4 & 2.051 & 1.1218 \\
\hline $\mathrm{K}(\%)$ & 0.23 & 8.78 & 4.1092 & 1.9968 \\
\hline $\mathrm{K}(\mathrm{cpc})$ & 0.7 & 13.5 & 6.478 & 3.0579 \\
\hline $\mathrm{TC}(\mathrm{cpc})$ & 300.4 & 638.0 & 447.761 & 58.3806 \\
\hline $\begin{array}{c}\text { Dose } \\
\text { (nGyph-1) }\end{array}$ & 33.45 & 676.49 & 300.512 & 149.7046 \\
\hline
\end{tabular}

Table 4: Ratio of Activity Value of Radionuclides

\begin{tabular}{|c|c|c|c|}
\hline Ratio & Min & Max & Mean \\
\hline $\mathrm{U} / \mathrm{Th}$ & 0.048 & 1.0 & 0.3122 \\
\hline $\mathrm{Th} / \mathrm{K}$ & 4.265 & 51.154 & 16.647 \\
\hline $\mathrm{U} / \mathrm{K}$ & 0.374 & 17.391 & 4.765 \\
\hline $\mathrm{Th} / \mathrm{U}$ & 1 & 20.706 & 4.025 \\
\hline $\mathrm{K} / \mathrm{Th}$ & 0.020 & 180.234 & 0.077 \\
\hline $\mathrm{K} / \mathrm{U}$ & 0.058 & 2.677 & 0.284 \\
\hline
\end{tabular}

Table 5: Correlation of ${ }^{40} \mathrm{~K},{ }^{238} \mathrm{U}$ and ${ }^{232} \mathrm{Th}$

\begin{tabular}{|c|c|c|c|}
\hline & ${ }^{40} \mathrm{~K}$ & ${ }^{238} \mathrm{U}$ & ${ }^{232} \mathrm{Th}$ \\
\hline${ }^{40} \mathrm{~K}$ & 1.00 & & \\
\hline${ }^{238} \mathrm{U}$ & 0.802 & 1.00 & \\
\hline${ }^{232} \mathrm{Th}$ & 0.822 & 0.888 & 1.00 \\
\hline
\end{tabular}

Other than numerical, pictural comparative of gamma-ray activity of the radioelements in the study area along each profile, the gamma-ray spectrometric data acquired were plotted and presented in bar charts (Fig. 12-14).

\section{Profile Three}

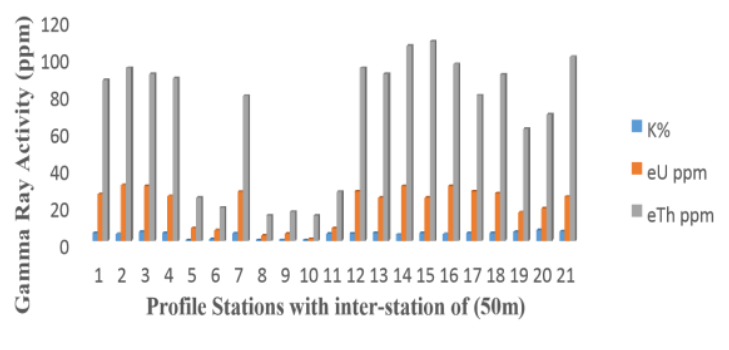

Figure 12: Bar Chart of mean gamma-ray activity of $\mathrm{U}$, Th and $\mathrm{K}$ along Profile Three 


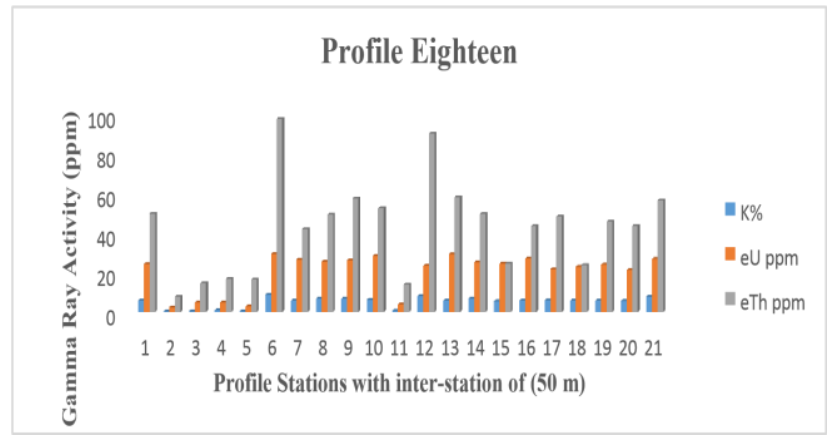

Figure 13: Bar Chart of mean gamma-ray activity of $\mathrm{U}$, Th and $\mathrm{K}$ along Profile Eighteen

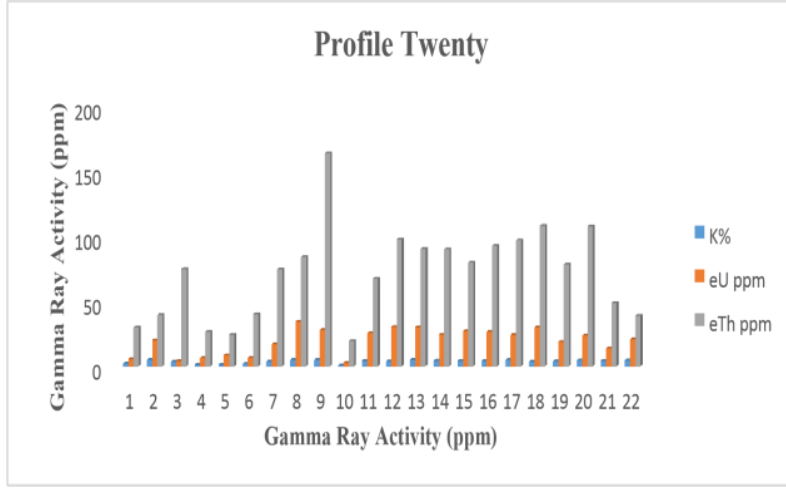

Figure 14: Bar Chart of mean gamma-ray activity of U, Th and K along Profile Twenty

The study of geological maps together with radiometric data to establish correlations between the two, the interpretation of gamma ray survey should be directed towards applying geologic knowledge on the processes that control the distribution of radioelements in rocks and soils to the enhancement and processing of the data. It is in this regard that concentration of radioelements ${ }^{238} \mathrm{U},{ }^{232} \mathrm{Th}$ and ${ }^{40} \mathrm{~K}$ were overlayed on geologic map of the study area so as to see variation(s) in the concentrations of the radionuclides with geology formation as presented in (Figures 15-18).

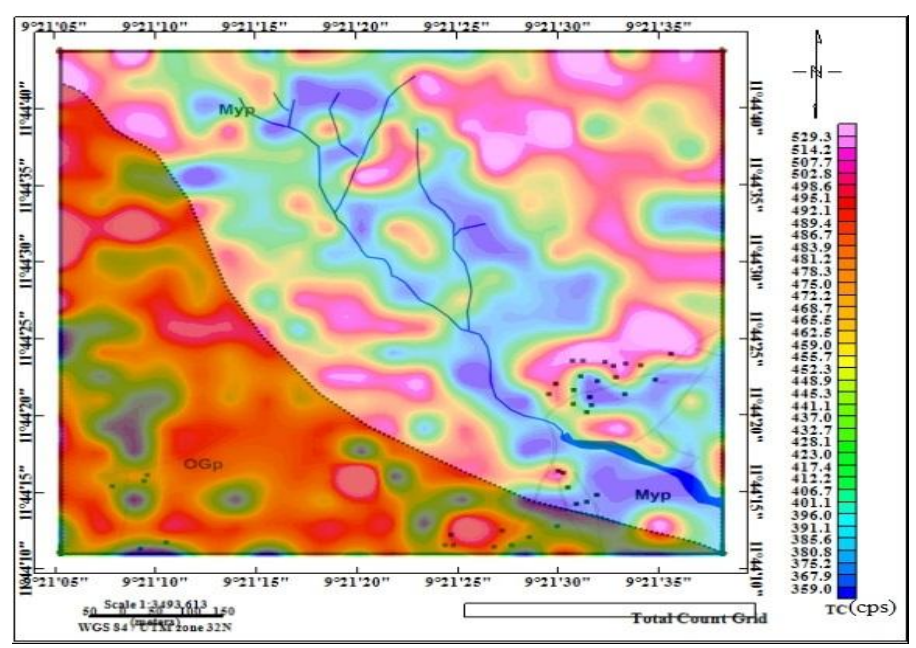

Figure 15: Total Count Grid overlayed on Geological Map

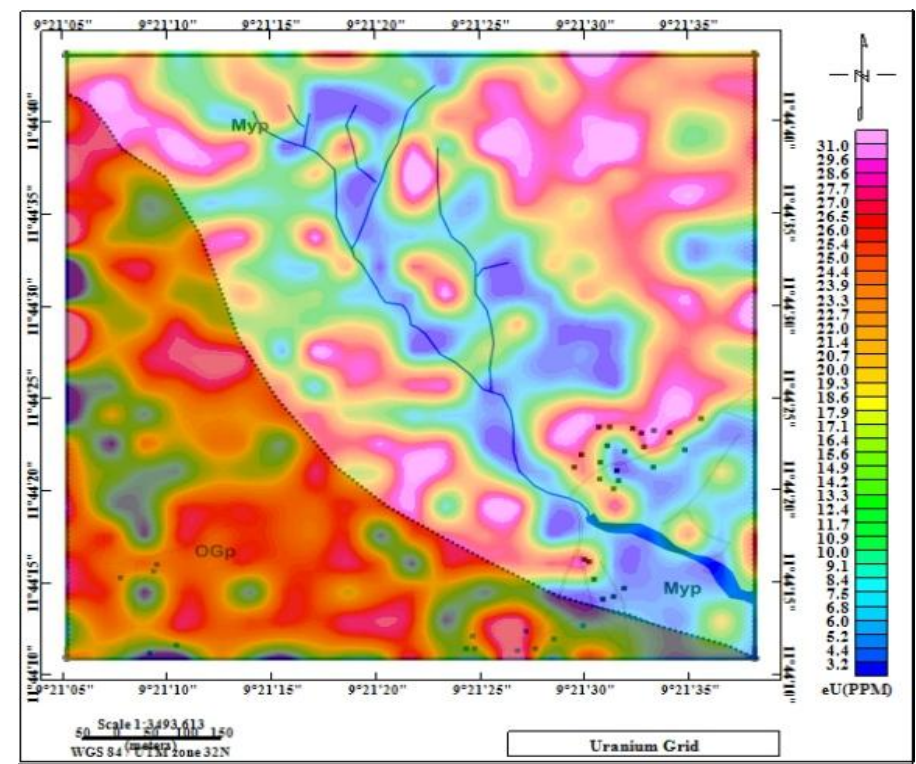

Figure 16: Uranium Grid overlayed on Geological Map

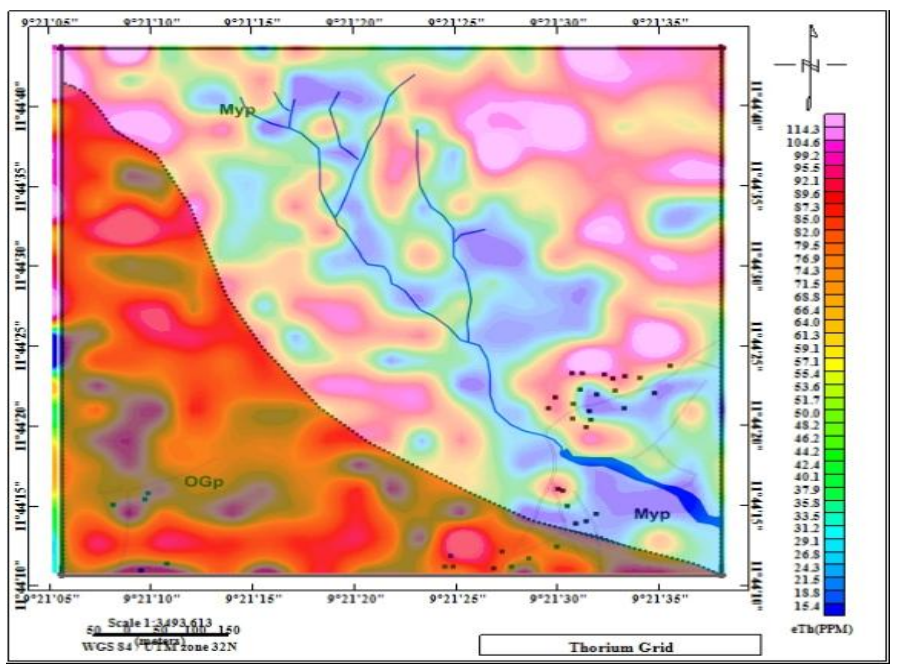

Figure 17: Thorium Grid overlayed on Geological Map

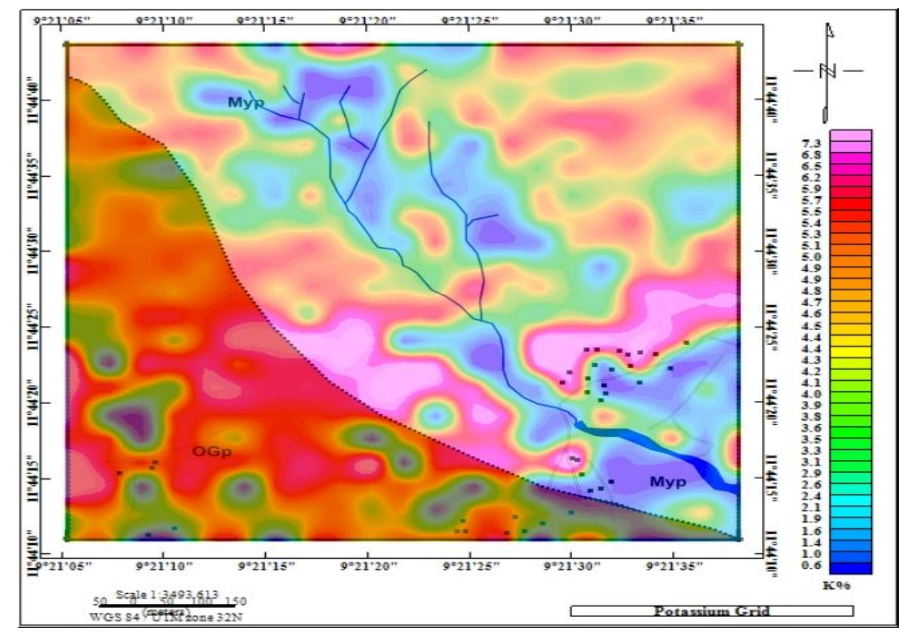

Figure 18: Potasium Grid overlayed on Geological Map 


\section{IV.CONCLUSION}

Ground radiometric survey was successfully conducted at Gaya LG of the present Jigawa State using spectrometer. Research revealed that both uranium and thorium are enriched in the youngest, most felsic and most potassic members of igneous rocks which is a good indicator for magmatic to postmagmatic alteration processes. (Hatem et al, 2014). The concentration of potassium in south-western and south-eastern part could be associated with the deposition of materials highly rich in feldspar into the lowland. Statistical analysis enumerated the order of radioelements concentration as $(\mathrm{Th}>\mathrm{U}>\mathrm{K})$ which surface the enrichment of Potassium over Uranium and Thorium as investigated by Hunting Geology and Geophysics Limited (1975)

\section{REFERENCE}

[1] Garba I. A rare earth element (REE) study of Bin Yauri gold deposit, Nigeria. Trans Inst Min Metall 1992; 80B:158-61.
[2] Hunting Geology and Geophysics Limited; Nigeria Aerospectrometric Maps 1975

[3] NGSA. Geological map of Nigeria. Nigerian Geological Survey Agency, Abuja, Nigeria, 2006

[4] Olofin. Some Aspect of the Physical Geography of the Kano Region and Related Human

[5] Responses, Departmental Lecture Note Series No.1 Geography Department,

Bayero University Kano, Debis Standard Press, Kano, 1987.

[6] Orgun Y, Altinsoy N, Sahin SY, Gungor Y, Gultekin AH, Karaham G, Karaak Z. Natural and Anthropogenic Radionuclides in rocks and beach sands from Ezine Region (Canakkale), Wester Anatolia, Turkey. Appl Radiat Isot 2007; 65:739-47.

[7] Salem A, Abouelhoda E, Alaa A, Atef I, Sachio E, Keisuke U. Mapping radioactive heat production from airborne spectral gamma-ray data of Gebel Duwi Area,Egypt.

[8] Proceedings World Geothermal Congress, Antalya, turkey, pp 249, 2005.

[9] Turner DC. Upper proterozoic schist belts in the Nigerian sector of the Pan-African province of West Africa. Precambr Res 1983; 21:55-79. 